\title{
Missing Links in Epithelial-Mesenchymal Transition: Long Non-Coding RNAs Enter the Arena
}

\author{
Lei Wang ${ }^{a}$ Fan Yang ${ }^{b}$ Lin-Tao Jia ${ }^{a}$ An-Gang Yang ${ }^{c}$
}

aState Key Laboratory of Cancer Biology, Department of Biochemistry and Molecular Biology, Fourth Military Medical University, Xi'an, Shaanxi, 'bState Key Laboratory of Military Stomatology and National Clinical Research Center for Oral Diseases and Shaanxi Key Laboratory of Stomatology, Department of Operative Dentistry and Endodontics, School of Stomatology, Fourth Military Medical University, Xi'an, 'Department of Immunology, Fourth Military Medical University, Xi'an, Shaanxi, China

\section{Key Words}

Long non-coding RNA • Epithelial-Mesenchymal Transition • Tumor metastasis • Crosstalk

\begin{abstract}
Cancer metastasis occurs through a series of sequential steps, which involves dissemination of tumor cells from a primary site and colonization in distant tissues. To promote the invasion-metastasis cascade, carcinoma cells usually initiate a cell-biological program called epithelial-mesenchymal transition (EMT), which is orchestrated by a set of master regulators, including TGF- $\beta$, Snail, ZEB and Twist families. The biological activities of these molecules are tightly regulated by a variety of cell-intrinsic pathways as well as extracellular cues. Recently, accumulating evidence indicates that long non-coding RNAs (IncRNAs) represent some of the most differentially expressed transcripts between primary and metastatic cancers. LncRNAs including MALAT1, HOTAIR, H19, LnCRNA-ATB, and LincRNA-ROR have been reported to be involved in the process of EMT, mainly through cross-talking with master regulators of EMT. Thus, understanding the different and precise molecular mechanisms by which functional IncRNAs switch EMT on and off is important for opening up new avenues in IncRNA-directed diagnosis, prognosis, and therapeutic intervention against cancer.
\end{abstract}

\section{Introduction}

(C) 2017 The Author(s) Published by S. Karger AG, Basel

The epithelial-mesenchymal transition (EMT), initially recognized as essential during embryonic development, has more recently been implicated in promoting carcinoma invasion and metastasis. The full accomplishment of the EMT process requires a complex genetic program that, together with the loss of the epithelial character, implies the acquisition of mesenchymal and motility properties. EMT can be exploited by normal or

L. Wang and F. Yang contributed equally to this work.

Lei Wang
and An-Gang Yang

KARGER
State Key Laboratory of Cancer Biology, Department of Biochemistry and Molecular Biology, Department of Immunology, Fourth Military Medical University, Xi'an, Shaanxi, (China) E-Mail rnawangl@yeah.net, agyang@fmmu.edu.cn 


\section{Cellular Physiology Cell Physiol Biochem 2017;44:1665-1680

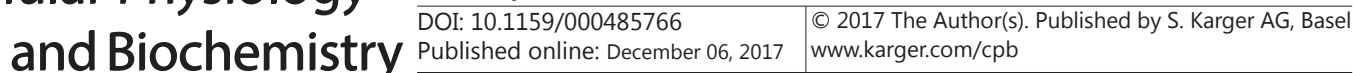

Wang et al.: Role of IncRNAs in Epithelial-Mesenchymal Transition

tumor epithelial cells to enable them to dissociate from their neighbours and migrate [1]. Several transcription factors have been identified as master regulators of EMT, including Snail, ZEB and Twist families, and their expression is tightly regulated at different steps of transcription, translation and protein stability control by a variety of cell-intrinsic pathways as well as extracellular cues [2]. A full understanding of the gene regulation network during this transition is essential but still far beyond completion.

Long non-coding RNAs (lncRNAs) are a large class of transcripts longer than 200 nucleotides with limited protein coding potential [3]. Presently, only a small number of IncRNAs have been characterized functionally, and most of them are shown to exert their effects by regulating various aspects of gene expression, such as transcription, splicing, translation, protein stability control, etc [4-10] (Fig. 1). Many lncRNAs are shown to regulate important cancer hallmarks, including proliferation [11], senescence [12], apoptosis [13], metablism [14], drug-resistance [15], and metastasis [16, 17]. Metastases are the major cause of death from cancer [18] and probably derived from primary tumor cells that have undergone EMT [19]. Recently, an increasing number of studies report that lncRNAs represent some of the most differentially expressed transcripts between primary and metastatic cancers $[20,21]$. Therefore, the crosstalk between lncRNAs and EMT regulators is an important topic in the field of cancer metastasis, and lncRNAs may be the missing links in the well-known EMT networks.

Here, we provide updated and new perspectives on recent advances made in understanding lncRNA mechanisms underlying EMT and tumor metastasis. We highlight, when possible, the mechanisms by which the IncRNAs function and how they are themselves regulated. We explore several known lncRNAs, which may potentially be involved in EMT as well as those which have only recently been discovered and provide interesting targets for further characterization.

\section{LncRNAs involved in EMT and tumor metastasis}

\section{MALAT1}

Metastasis-associated lung adenocarcinoma transcript 1(MALAT1), also known as NEAT2, is one the most well-known lncRNAs which have an important role in metastasis. Early report showed that patients with non-small cell lung cell cancer (NSCLC) exhibiting high expression of the MALAT1 transcript were five times more likely to develop metastasis compared to those with low expression [22]. Since this discovery, investigations have been initiated to characterize the MALAT1 transcript and the mechanisms by which it functions. MALAT1 is highly conserved amongst mammals and highly expressed in the nucleus [23]. It regulates the expression of metastasis-associated genes [24] and enhances cell motility by influencing the expression of motility-related genes [25]. Interestingly, recent data revealed that MALAT1 could facilitate tumor metastasis by promoting EMT properties. For example, Ying and colleagues found that MALAT1 expression was remarkably increased in metastatic bladder cancer compared with primary tumors. Using an in vitro model, they demonstrated that MALAT1 promoted EMT by activating Wnt signaling. Downregulation of MALAT1 resulted in a decrease of the EMT-associated ZEB1, ZEB2 and Slug levels, and an increase of E-cadherin levels [26]. Mechanistic study revealed that MALAT1 is associated with suppressor of zeste 12(SUZ12) and this association results in decrease of E-cadherin expression and increase of $\mathrm{N}$-cadherin and fibronectin expression [27]. Moreover, MALAT1 was reported to upregulate Snail expression to promote EMT process in colon cancer [28]. Recent studies also showed that MALAT1 could function as a competitive endogenous RNA (ceRNA) for multiple EMTsuppressive miRNAs, such as miR-200c in endometrioid endometrial carcinoma [29], miR124 in nasopharyngeal carcinoma [30], and miR-218 in colorectal cancer [31]. In another study conducted in patients with NSCLC, Shen and colleagues discovered that MALAT1 promoted lung cancer brain metastasis via the induction of EMT [32]. However, a recent study demonstrated that, by forming a ribonucleic complex with the RNA-binding protein 


\section{Cellular Physiology Cell Physiol Biochem 2017;44:1665-1680 \\ \begin{tabular}{l|l} 
DOI: 10.1159/000485766 & $\begin{array}{l}\text { O 2017 The Author(s). Published by S. Karger AG, Basel } \\
\text { www.karger.com/cpb }\end{array}$
\end{tabular}}

Wang et al.: Role of IncRNAs in Epithelial-Mesenchymal Transition

HuR, MALAT1 binds the CD133 promoter region to repress its expression and suppresses EMT in breast cancer (Fig. 2b, ii) [33]. Thus, further studies are necessary to understand the precise role of MALAT1 in EMT and metastasis and the molecular determinants of its function.

\section{HOTAIR}

HOX transcript antisense intergenic RNA (HOTAIR), one of the first lncRNAs described to have a fundamental role in cancer metastasis, is located in the HOXD locus and exhibits cell-type and tissue-specific expression patterns [34]. HOTAIR expression is upregulated in malignant tissues and is associated with an increase in invasion and metastasis in breast, lung, colorectal, and hepatocellular carcinoma [35-38]. Mechanistic study revealed that enforced expression of HOTAIR in epithelial cancer cells induced genome-wide re-targeting of Polycomb repressive complex 2 (PRC2) to an occupancy pattern more resembling embryonic fibroblasts, leading to altered histone $\mathrm{H} 3$ lysine 27 methylation and gene expression [35]. Similar to MALAT1, recent data demonstrated that HOTAIR overexpression is also closely related to enhanced EMT characteristics. A study conducted by Padua et al. revealed that HOTAIR is required for EMT and stemness maintenance of cancer cell lines [39]. They found that treating cells with transforming growth factor-beta (TGF- $\beta$ ) resulted in increased HOTAIR expression and triggered the EMT program, while ablation of HOTAIR expression by siRNA prevented the EMT program stimulated by TGF- $\beta 1$. In another study conducted in colon cancer cell lines, Wu et al. found that depletion of HOTAIR led to increased expression of E-cadherin and downregulation of Vimentin and MMP9, suggesting that HOTAIR may be a pleiotropic modulator participating in EMT [40]. Further study revealed that HOTAIR-PRC2 complex epigenetically silences a tumor-suppressive microRNA miR-34a, which controls the downstream targets c-Met (HGF/c-Met/Snail pathway) and Snail, thus contributing to the process of EMT and tumor metastasis in gastric cancer (Fig. 2b, i) [41]. Moreover, Wu et al. demonstrated that HOTAIR contributes to the direct suppression of E-cadherin by recruiting enhancer of zeste homolog 2 (EZH2) to the E-cadherin promoter [42]. Supporting evidence were found that HOTAIR expression levels were negatively correlated with those of E-cadherin in gastric cancer and oral squamous cell carcinoma tissues [41,42]. Besides, Hong et al. demonstrated that HOTAIR also functions as a ceRNA for miR-217, thus regulating HIF$1 \alpha /$ AXL signaling and promoting EMT process in renal cell carcinoma [43]. Despite much progress in recent years, our knowledge of the relationship between HOTAIR and EMT is still unsatisfactory and further studies are necessary to understand the precise role of HOTAIR in the process of EMT.

\section{H19}

The H19 gene belongs to a highly conserved imprinted gene cluster that plays important roles in embryonal development and growth control. H19 expression is strongly induced during embryogenesis and downregulated after birth, except in adult skeletal muscle and heart. Over the last decade, a role for H19 acting either as a tumor suppressor [44] or an oncogene [45] has been reported. Since then, accumulating evidence suggests that H19 is also significantly associated with EMT process and tumor metastasis. In a study conducted in hepatocellular carcinoma (HCC), Zhang et al. revealed that $\mathrm{H} 19$ associates with the protein complex hnRNP U/PCAF/RNApol II and activates miR-200 family (pivotal repressors of EMT [46]) by increasing histone acetylation, thus contributing to mesenchymal-to-epithelial transition (MET) and suppression of tumor metastasis [47]. In another study conducted in prostate cancer, Zhu et al. found that H19 and H19-derived miR-675 were significantly downregulated in the metastatic prostate cancer cell line compared with the non-metastatic prostate epithelial cell line. Ectopic expression of H19 resulted in increased level of miR-675, which directly binds to the 3'UTR of TGFBI (an extracellular matrix protein involved in EMT and cancer metastasis) mRNA to repress its translation [48]. However, several other works demonstrated that $\mathrm{H} 19$ may promote the EMT process rather than impeding it $[49,50]$. Luo et al. found that $\mathrm{H} 19$ levels are remarkably upregulated in bladder cancer tissues, and ectopic 
expression of $\mathrm{H} 19$ promotes bladder cancer cell migration in vitro and in vivo. Mechanistic study demonstrated that $\mathrm{H} 19$ is associated with EZH2, which results in Wnt/ $\beta$-catenin activation and subsequent repression of E-cadherin [49]. Moreover, Matouk et al. found that H19 expression level was tightly correlated with tumor metastatic potential and numerous established inducers of EMT (such as TGF- $\beta$ and hypoxia) could upregulate H19 and miR675 concomitantly with the induction of EMT markers. Through a mechanism involving miR675, H19 upregulated Slug expression and decreased E-cadherin protein level. Interestingly, Slug also activated the promoter of $\mathrm{H} 19$ gene and upregulated its expression, thus forming a positive feedback loop between Slug and H19/miR-675, which regulates E-cadherin expression [50]. In a recent study, Zhou et al. revealed that H19 could mediate breast cancer cell plasticity during the EMT and MET processes by differentially sponging miR-200b/c and let-7b [51]. Taken together, the above data suggest that the functional role that $\mathrm{H} 19$ exerts in EMT and tumor metastasis is context-dependent and should be investigated carefully.

\section{LnCRNA-ATB}

LncRNA activated by TGF- $\beta$ (LncRNA-ATB) was recently described to promote the invasion-metastasis cascade in HCC [52]. As its name suggests, LncRNA-ATB is induced by TGF- $\beta$ in multiple cancer types, including breast, colorectal, gastric, and hepatocellular carcinoma [52-55]. LncRNA-ATB plays an essential role in both the early-stage invasion process and the late-stage colonization phase of metastasis in vivo [52]. Mechanistic study demonstrated that the functional role that LncRNA-ATB plays in early-stage invasion is closely related to the EMT process. By competitively binding the miR-200 family, LncRNAATB upregulated ZEB1 and ZEB2 expression and then induced EMT (Fig. 2b, iii). Depletion of LncRNA-ATB abrogated TGF- $\beta$-induced EMT in vitro and decreased the number of circulating tumor cells (CTCs) in whole blood from orthotopic tumor models in vivo, in a miR-200dependent manner. However, miR-200 overexpression only partially rescued LncRNA-ATBinduced metastasis in vivo, indicating the involvement of additional downstream players. Indeed, LncRNA-ATB stabilized interleukin-11 (IL-11) mRNA and elevated IL-11 secretion, thus activating STAT3 signaling which promotes organ colonization of disseminated tumor cells [52]. In another study conducted in HER2-positive breast cancer, Shi et al. found that LncRNA-ATB was remarkably upregulated in trastuzumab-resistant breast cancer cell lines and tissues. They demonstrated that LncRNA-ATB could promote trastuzumab resistance and invasion-metastasis cascade in HER2-positive breast cancer by competitively binding miR-200c, thus upregulating ZEB1 and ZNF-217, and then inducing EMT [53]. Despite much progress in recent years, our knowledge of the relationship between LncRNA-ATB and EMT is still limited and further studies are necessary to understand the versatile roles exerted by LncRNA-ATB.

\section{LincRNA-ROR}

First identified as a lincRNA whose expression is linked to pluripotency [56], lincRNAregulator of reprogramming (LincRNA-ROR) is now considered to play a crucial role in the process of EMT and tumor metastasis. High expression of LincRNA-ROR is observed in multiple cancer types, including breast, bladder, and nasopharyngeal carcinoma [57-59]. Ectopic expression of LincRNA-ROR in cancer cells was associated with enhanced migration, invasion and EMT in vitro and metastasis in vivo. Mechanistically, The EMT-promoting effects of LincRNA-ROR are mostly attributed to its function as a miRNA sponge for several key miRNAs. One such miRNA is miR-205, a tumor-suppressive miRNA which targets ZEB1 and ZEB2. Silencing of LincRNA-ROR promoted the degradation of miR-205 target genes, resulting in impaired EMT and metastatic potential [57]. miR-145, a well-known miRNA commonly downregulated in various cancers [60], is another miRNA that can be competitively absorbed by LincRNA-ROR. In a study conducted in triple-negative breast cancer, Eades et al. found that LincRNA-ROR could competitively bind miR-145, which targets small GTPase ADPribosylation factor 6 (ARF6), leading to enhanced endocytosis of E-cadherin and reduced cell-cell adhesion [61]. It is worth noting that LincRNA-ROR transcripts were quite abundant 
Table 1. LncRNAs involved in EMT and tumor metastasis

\begin{tabular}{|c|c|c|c|c|c|}
\hline LncRNA & Description & $\begin{array}{l}\text { Changes in } \\
\text { cancer }\end{array}$ & $\begin{array}{l}\text { Expression } \\
\text { correlation with } \\
\text { tumor metastasis }\end{array}$ & Known molecular mechanisms & References \\
\hline BANCR & $\begin{array}{l}\text { BRAF-activated non- } \\
\text { coding RNA }\end{array}$ & Up/Down & Positive/ Negative & $\begin{array}{l}\text { Activates the ERK pathway/ Upregulates E-cadherin, } \\
\text { downregulates N-cadherin and Vimentin }\end{array}$ & $\begin{array}{l}\text { Melanoma [63], CRC } \\
\text { [64], NSCLC [65] }\end{array}$ \\
\hline CCAT1 & $\begin{array}{l}\text { Colon cancer associated } \\
\text { transcript-1 }\end{array}$ & Up & Positive & Upregulates CCND1/ Acts as a ceRNA for miR-181b & $\begin{array}{l}\text { CRC [66], Pancreatic } \\
\text { [67], Glioma [68] }\end{array}$ \\
\hline CCAT2 & $\begin{array}{l}\text { Colon cancer associated } \\
\text { transcript-2 }\end{array}$ & Up & Positive & $\begin{array}{l}\text { Upregulates ZEB2, N-cadherin and Vimentin, downregulates E- } \\
\text { cadherin }\end{array}$ & $\begin{array}{l}\text { Prostate [69], } \\
\text { Glioma [70], Gastric } \\
\text { [71] }\end{array}$ \\
\hline GHET1 & $\begin{array}{l}\text { Gastric carcinoma highly } \\
\text { expressed transcript } 1\end{array}$ & Up & Positive & $\begin{array}{l}\text { Physically associates with IGF2BP,increases the stability of c- } \\
\text { Myc }\end{array}$ & $\begin{array}{l}\text { Gastric [72], Bladder } \\
\text { [73] }\end{array}$ \\
\hline H19 & $\begin{array}{l}\text { H19, imprinted } \\
\text { maternally expressed } \\
\text { transcript }\end{array}$ & Up/Down & Positive/ Negative & $\begin{array}{l}\text { Activates miR-200 family/ Upregulates miR- } 675 \text { to repress } \\
\text { TGFBI expression/Activates the Wnt/ } \beta \text {-catenin pathway/ } \\
\text { Upregulates Slug, downregulates E-cadherin/ Acts as a ceRNA } \\
\text { for let-7b, miR-200b/c, and miR-141 }\end{array}$ & $\begin{array}{l}\text { HCC [47], Prostate } \\
\text { [48], Bladder [49], } \\
\text { Breast [50,51] } \\
\text { Gastric [74] }\end{array}$ \\
\hline $\begin{array}{l}\text { HNF1A- } \\
\text { AS1 }\end{array}$ & HNF1A antisense RNA 1 & Up & Positive & $\begin{array}{l}\text { Upregulates H19, modulates chromatin and nucleosome } \\
\text { assembly/ Upregulates CCND1, N-cadherin and } \beta \text {-catenin, } \\
\text { downregulates E-cadherin }\end{array}$ & EAC [75], LAC [76] \\
\hline HOTAIR & $\begin{array}{l}\text { HOX transcript antisense } \\
\text { RNA }\end{array}$ & Up & Positive & $\begin{array}{l}\text { Activated by TGF- } \beta \text { / Silences miR-34a by binding to PRC2/ } \\
\text { Upregulates Vimentin and MMP9, downregulates E-cadherin/ } \\
\text { Acts as a ceRNA for miR-217 to upregulate HIF-1 } \alpha\end{array}$ & $\begin{array}{l}\text { Breast }[35,39] \text {, } \\
\text { Colon }[36,40] \text {, } \\
\text { Gastric }[41], \text { OSCC } \\
{[42],} \\
\text { RCC }[43], \text { NSCLC } \\
{[777]}\end{array}$ \\
\hline HOTTIP & $\begin{array}{l}\text { HOXA distal transcript } \\
\text { antisense RNA }\end{array}$ & Up & Positive & $\begin{array}{l}\text { Upregulates HOXA9 by forming Twist1-WDR5-HOTTIP } \\
\text { complex/ Upregulates HOXA13 }\end{array}$ & $\begin{array}{l}\text { Prostate [78], } \\
\text { Pancreatic [79] }\end{array}$ \\
\hline HULC & $\begin{array}{l}\text { Highly up-regulated in } \\
\text { liver cancer }\end{array}$ & Up & Positive & Acts as a ceRNA for miR-200a to upregulate ZEB1 & $\begin{array}{l}\text { Gastric [80], HCC } \\
{[81]}\end{array}$ \\
\hline $\begin{array}{l}\text { LincRNA- } \\
\text { ROR }\end{array}$ & $\begin{array}{l}\text { LincRNA-Regulator of } \\
\text { reprogramming }\end{array}$ & Up & Positive & $\begin{array}{l}\text { Acts as a ceRNA for miR-205 to upregulate ZEB2/ Acts as a } \\
\text { ceRNA for miR-145 to upregulate ARF6 }\end{array}$ & $\begin{array}{l}\text { Breast [57,82], } \\
\text { Pancreatic [83] }\end{array}$ \\
\hline $\begin{array}{l}\text { LncRNA- } \\
\text { ATB }\end{array}$ & $\begin{array}{l}\text { LncRNA-activated by } \\
\text { TGF- } \beta\end{array}$ & Up & Positive & $\begin{array}{l}\text { Acts as a ceRNA for miR-200 family to upregulate ZEB1, ZEB2 } \\
\text { and ZNF217 }\end{array}$ & $\begin{array}{l}\text { HCC [52], Breast } \\
\text { [53], CRC [84] }\end{array}$ \\
\hline $\begin{array}{l}\text { LnCRNA- } \\
\text { EBIC }\end{array}$ & $\begin{array}{l}\text { EZH2-binding lncRNA in } \\
\text { cervical cancer }\end{array}$ & Up & Positive & Binds to EZH2 and represses E-cadherin & Cervical [85] \\
\hline $\begin{array}{l}\text { LncRNA- } \\
\mathrm{Hh}\end{array}$ & $\begin{array}{l}\text { Hedgehog signaling } \\
\text { associated lncRNA }\end{array}$ & Up & Unknown & $\begin{array}{l}\text { Induced by Twist, directly targets GAS1 to activate hedgehog } \\
\text { signaling }\end{array}$ & Breast [86] \\
\hline $\begin{array}{l}\text { LncRNA- } \\
\text { HIT }\end{array}$ & $\begin{array}{l}\text { HOXA-associated } \\
\text { transcript induced by } \\
\text { TGF- } \beta\end{array}$ & Up & Positive & Activated by TGF- $\beta$, downregulates E-cadherin & Breast [87] \\
\hline IncTCF7 & $\begin{array}{l}\text { WNT Signaling Pathway } \\
\text { Activating Non-Coding } \\
\text { RNA }\end{array}$ & Up & Positive & $\begin{array}{l}\text { Activated by IL/STAT3 signaling, upregulates Vimentin, } \\
\text { downregulates E-cadherin }\end{array}$ & HCC [88] \\
\hline MALAT1 & $\begin{array}{l}\text { Metastasis-associated } \\
\text { lung adenocarcinoma } \\
\text { transcript } 1\end{array}$ & Up & Positive & $\begin{array}{l}\text { Activated by TGF- } \beta \text { / Associates with SUZ12 to repress E- } \\
\text { cadherin and upregulate N-cadherin and fibronectin/ Forms } \\
\text { HuR-MALAT1 complex to repress CD133 Expression }\end{array}$ & $\begin{array}{l}\text { NSCLC [22,32], } \\
\text { Bladder [26,27], } \\
\text { OSCC [89] }\end{array}$ \\
\hline MEG3 & $\begin{array}{l}\text { Maternally expressed } \\
\text { gene } 3\end{array}$ & Down & Negative & $\begin{array}{l}\text { Silences E-cadherin and miR-200 family by binding to JARID2 } \\
\text { and EZH } 2 \text { / Inhibits Rac } 1 \text { at posttranscriptional level / Acts as a } \\
\text { ceRNA for miR- } 421 \text { to upregulate E-cadherin }\end{array}$ & $\begin{array}{l}\text { Lung [90], Breast } \\
\text { [91], Thyroid [92] }\end{array}$ \\
\hline NEAT1 & $\begin{array}{l}\text { Nuclear enriched } \\
\text { abundant transcript } 1\end{array}$ & Up & Positive & $\begin{array}{l}\text { Upregulates } \beta \text {-catenin and N-cadherin, downregulates E- } \\
\text { cadherin/ Upregulates ZEB1 by repressing miR-204 }\end{array}$ & $\begin{array}{l}\text { ccRCC [93], NPC } \\
\text { [94], Breast [95] }\end{array}$ \\
\hline $\begin{array}{l}\text { PlncRNA- } \\
1\end{array}$ & NA & Up & Positive & $\begin{array}{l}\text { Upregulates Vimentin and } \mathrm{N} \text {-cadherin, downregulates } \mathrm{E} \text { - } \\
\text { cadherin }\end{array}$ & HCC $[96]$ \\
\hline PVT1 & $\begin{array}{l}\text { Plasmacytoma variant } \\
\text { translocation } 1 \text { gene }\end{array}$ & Up & Positive & $\begin{array}{l}\text { Upregulates ZEB1, Snail and N-cadherin, downregulates p } 21 \\
\text { and E-cadherin }\end{array}$ & $\begin{array}{l}\text { Pancreatic [97], } \\
\text { Esophageal [98] }\end{array}$ \\
\hline SNHG6 & $\begin{array}{l}\text { Small Nucleolar RNA } \\
\text { Host Gene } 6\end{array}$ & Up & Positive & Acts as a ceRNA for miR-101 to upregulate ZEB1 & Gastric [99] \\
\hline $\begin{array}{l}\text { SPRY4- } \\
\text { IT1 }\end{array}$ & $\begin{array}{l}\text { SPRY4 intronic } \\
\text { transcript } 1\end{array}$ & Up/Down & Positive/ Negative & $\begin{array}{l}\text { Epigenetically silenced by EZH2/ Downregulates E-cadherin, } \\
\text { upregulates Vimentin }\end{array}$ & $\begin{array}{l}\text { NSCLC [100], Gastric } \\
\text { [101], Glioma [102] }\end{array}$ \\
\hline TUG1 & $\begin{array}{l}\text { Taurine up-regulated } \\
\text { gene } 1\end{array}$ & Up & Positive & $\begin{array}{l}\text { Activated by TGF- } \beta \text { / Acts as a ceRNA for miR-145 to upregulate } \\
\text { ZEB2/ Acts as a ceRNA for miR-300 }\end{array}$ & $\begin{array}{l}\text { CRC [103], Bladder } \\
\text { [104], Gallbladder } \\
\text { [105] }\end{array}$ \\
\hline treRNA & $\begin{array}{l}\text { Translational regulatory } \\
\text { IncRNA }\end{array}$ & Up & Positive & $\begin{array}{l}\text { Suppresses the translation of E-cadherin mRNA/ Silenced by } \\
\text { miR-190a at posttranscriptional level }\end{array}$ & $\begin{array}{l}\text { Breast }[106], \mathrm{HCC} \\
{[107]}\end{array}$ \\
\hline UCA1 & $\begin{array}{l}\text { Urothelial cancer } \\
\text { associated } 1\end{array}$ & Up & Positive & $\begin{array}{l}\text { Activated by TGF- } \beta \text { / Acts as a ceRNA for miR- } 145 \text { to upregulate } \\
\text { ZEB1 and ZEB2/ Upregulates N-cadherin, Vimentin and Snail, } \\
\text { downregulates E-cadherin }\end{array}$ & $\begin{array}{l}\text { Bladder [108], } \\
\text { Breast [109], Gastric } \\
{[110]}\end{array}$ \\
\hline ZEB1-AS1 & ZEB1 antisense RNA 1 & Up & Positive & $\begin{array}{l}\text { Upregulates ZEB1 via enhancer-like mechanisms/ Upregulates } \\
\text { MMP2, MMP9, N-cadherin, and Integrin- } \beta 1 \text {, downregulates E- } \\
\text { cadherin }\end{array}$ & $\begin{array}{l}\text { HCC [111], Glioma } \\
{[112]}\end{array}$ \\
\hline ZFAS1 & ZNFX1 antisense RNA 1 & Up & Positive & $\begin{array}{l}\text { Acts as a ceRNA for miR-150 to upregulate ZEB1, MMP14 and } \\
\text { MMP16/ Downregulates E-cadherin and ZO-1,Upregulates } \\
\text { Vimentin and N-cadherin }\end{array}$ & $\begin{array}{l}\text { HCC [113], Gastric } \\
{[114], \text { Colon [115] }}\end{array}$ \\
\hline
\end{tabular}

in the cytoplasm of self-renewing embryonic stem cells (ESCs) [62], which supports the hypothesis that LincRNA-ROR interacted with miRNAs in the cytoplasm. However, other potential mechanisms underlying the EMT-promoting effects of LincRNA-ROR are likely to be involved and deserve further investigation in the near future (Table 1).

\section{Crosstalk between EMT regulators and IncRNAs}

\section{TGF- $\beta$ and LncRNAs}

The multifunctional cytokine TGF- $\beta$ orchestrates an intricate signaling network to modulate tumorigenesis and progression. TGF- $\beta$ exerts its tumor-suppressive role by inducing cell-cycle arrest and apoptosis. Nevertheless, TGF- $\beta$ also promotes tumor progression through enhancing proliferation, migration, and invasion, in part by its ability to induce EMT [116]. Recent evidence, addressing the crosstalk between the TGF- $\beta$ signaling pathway and IncRNAs in cancer, found that several members of the TGF- $\beta$ pathway are 
targeted by IncRNAs, and the production of hundreds of lncRNAs is induced by TGF- $\beta$ treatment (Fig. 2a). For example, Li et al. showed that knockdown of MALAT1 could inhibit TGF- $\beta$ production by modulating recruitment of transcription factor Sp1 to the LTBP3 gene promoter in mesenchymal stem cells from patients with multiple myeloma [117]. In addition, Fan et al. reported that TGF- $\beta$ could also induce MALAT1 expression and EMT in bladder cancer cells and targeted inhibition of MALAT1 suppressed the migratory and invasive properties induced by TGF- $\beta$ [27]. Maternally expressed gene 3 (MEG3), located in the imprinted DLK1-MEG3 locus on human chromosome 14q32.3, is another key lncRNA which could regulate TGF- $\beta$ pathway through epigenetic mechanisms. In a study conducted in breast cancer, Mondal et al. found that MEG3 and EZH2 share common target genes, including the TGF- $\beta$ pathway genes. Genome-wide mapping of MEG3 binding sites revealed that MEG3 modulates the activity of TGF- $\beta$ genes by binding to distal regulatory elements. MEG3 binding sites have GA-rich sequences, which guide MEG3 to the chromatin through RNA-DNA triplex formation [118]. Moreover, several other lncRNAs were reported to regulate the TGF- $\beta$ signaling pathway in a variety of different ways, including plasmacytoma variant translocation 1 (PVT1), p53 induced non-coding transcript (PINT), and Linc00974. Takahashi et al. demonstrated that PVT1 knockdown could upregulate Smad4 and apoptosisassociated genes related to the TGF- $\beta$ pathway [119]. Marin-Bejar et al. revealed that PINT could promote cell proliferation and survival by regulating the expression of genes of the TGF- $\beta$, MAPK and p53 pathways in mouse cells [120]. Linc00974 was reported to be involved in a Linc00974-miR-642-KRT19-TGF- $\beta$ signaling pathway [121]. In this study, Tang et al. revealed that Linc00974 hyperexpression could induce the upregulation of KRT19 via ceRNA network, resulting in the activation of the TGF- $\beta$ and Notch pathways as detected by cDNA microarray. Although our current knowledge on the complex role of lncRNAs in TGF- $\beta$ signaling pathways is poor, the IncRNAs remain of great therapeutic potential for antagonizing the deregulation of TGF- $\beta$ pathway in cancer. Further studies of the IncRNATGF- $\beta$ signaling network will definitely help expand our understanding of the pathogenesis of human malignancies.

\section{Snail/Slug and LncRNAs}

Of the three vertebrate Snail proteins, Snai1 (also known as Snail) and Snai2 (also known as Slug) activate the EMT programme during development, fibrosis and cancer [122]. Snail factors bind to E-box consensus sequences in the E-cadherin promoter with the help of local modifications of chromatin structure after the recruitment of SIN3A, histone deacetylases HDAC1 and HDAC2, and components of PRC2 complex. In addition to being tightly regulated at the transcriptional level, Snail factors undergo posttranslational modifications that control their nuclear localization or degradation [123]. In recent years, accumulating evidence suggests that Snail factors and IncRNAs could regulate each other reciprocally, thus adding another layer of complexity to the regulation of Snail activity (Fig. 2a). Orom et al. found that a set of lncRNAs exhibit enhancer-like function in human cell lines, and depletion of some of these IncRNAs led to decreased expression of their neighboring protein-coding genes, such as Snail and Slug [124]. It was reported previously that Snail protein could recruit chromatin modifier EZH2 to a broad repertoire of epithelial genes but the underlying mechanism remains largely unknown [125]. Recently, Battistelli et al. revealed that HOTAIR mediates a physical interaction between Snail and EZH2 and the Snail-repressive activity depends on the formation of a tripartite Snail/HOTAIR/EZH2 complex [126]. In a TGF- $\beta$-induced EMT model, Matouk et al. demonstrated that H19 could upregulate Slug expression concomitant with the suppression of E-cadherin protein through a mechanism involving miR-675. In turn, Slug also bound and activated the promoter of $\mathrm{H} 19$ to upregulate its expression, thus forming a positive feedback loop between Slug and H19/miR-675 [50]. Besides H19, several other IncRNAs are now reported to play a pivotal role in regulating the expression and activity of Snail factors, such as LINC01013 [127], lnc-GNAT1-1 [128], and Lnc-CC3 [129]. However, our current knowledge of the crosstalk between lncRNAs and Snail factors is still limited and further studies are necessary to understand the precise relationship between them. 


\section{Cellular Physiology Cell Physiol Biochem 2017;44:1665-1680

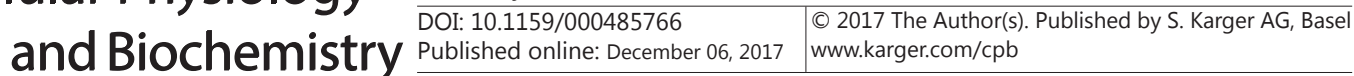

Fig. 1. Models of IncRNA mechanisms of action. (a) lncRNA expression can faithfully reflect the combinatorial actions of transcription factors or signaling pathways to indicate gene regulation in space and time. (b) IncRNAs can act as decoys that titrate away DNA-binding proteins, such as transcription factors. (c) lncRNAs can act as guides to recruit proteins, such as chromatin-modifying enzymes, to target genes. (d) lncRNAs may act as scaffolds to bring two or more proteins into a complex or spatial proximity. (e) IncRNAs may be integral components of the nuclear paraspeckle and contribute to posttranscriptional processing of mRNAs. (f) lncRNAs may harbor the recognition sites for functional miRNAs, thus titrate miRNAs away from their mRNA targets. (g) lncRNA/ mRNA duplexes can direct exosomemediated RNA degradation. (h) lncRNAs bound with the mRNA would positively or negatively modulate the translation efficiency, depending on the mRNA and IncRNA structures.

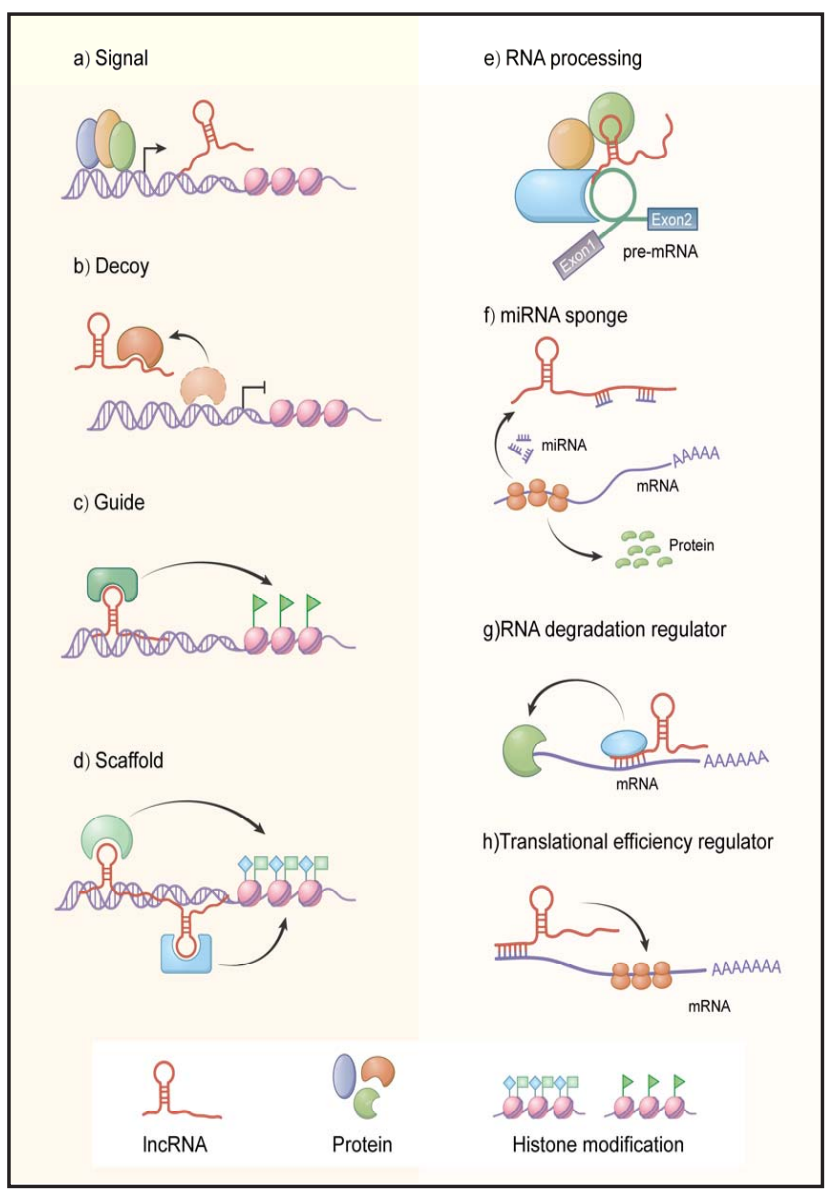

\section{ZEB and LncRNAs}

Like Snail proteins, ZEBs bind E-boxes and function as transcriptional repressors and activators, thereby repressing some epithelial junction and polarity genes and activating mesenchymal genes that define the EMT phenotype. ZEB expression often follows activation of Snail expression, consistent with Snail directly targeting the ZEB1 gene. Besides, numerous studies have reported that ZEB factors can also be regulated by other mechanisms such as miRNA-mediated gene silencing and Polycomb-mediated sumoylation [122]. Interestingly, recent work showed that lncRNAs are involved in regulation of ZEB in a variety of different ways (Fig. 2a). First, lncRNAs could upregulate ZEB expression via ceRNA regulatory networks. As mentioned above, Yuan et al. demonstrated that LncRNAATB upregulates ZEB1 and ZEB2 expression by competitively binding the miR-200 family, thus contributing to the EMT process (Fig. 2b, iii)[52]. ZFAS1, a lncRNA that is frequently amplified in HCC, functions as an oncogene in HCC progression by binding miR-150, thus derepressing its inhibitory effect on ZEB1 [113]. Moreover, Hou et al. found that LincRNAROR is associated with miRNPs and functions as a ceRNA for miR-205. Specifically, LincRNAROR prevents the degradation of miR-205 target genes, including the EMT inducer ZEB2 [57]. Secondly, lncRNAs could upregulate ZEB expression via enhancer-like mechanisms. In a study conducted in HCC, Li et al. revealed that an IncRNA named ZEB1-AS1 is frequently upregulated in HCC samples, especially in metastatic tumor tissues. The ZEB1-AS1 gene is located in physical contiguity with ZEB1 and positively regulates the ZEB1 expression. ZEB1 depletion partially abrogates ZEB1-AS1-induced EMT and tumor metastasis, suggesting ZEB1-AS1 and ZEB1 play a critical role in HCC progression [111]. Thirdly, IncRNAs also contribute to pathogenic splicing of ZEB genes. Beltran et al. found that maintenance of 5'- 


\section{Cellular Physiology Cell Physiol Biochem 2017;44:1665-1680

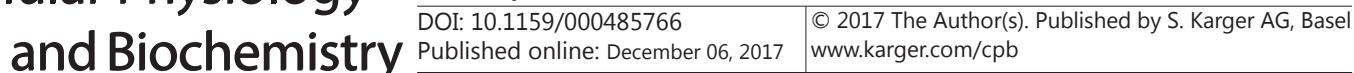

Wang et al.: Role of IncRNAs in Epithelial-Mesenchymal Transition

UTR ZEB2 intron is dependent on the expression of a natural antisense transcript (NAT) that overlaps the 5' splice site in the intron. Ectopic overexpression of NAT in epithelial cells prevents splicing of the ZEB2 5'-UTR, increases the levels of ZEB2 protein, and consequently downregulates E-cadherin mRNA and protein [130].

\section{Twist and LncRNAs}

As with Snail, Twist expression downregulates epithelial gene expression and activates mesenchymal gene expression. In cancer cells, Twist1 represses E-cadherin and induces $\mathrm{N}$-cadherin expression independently of Snail and probably through the association with other proteins. Recent study showed that more than 99 lncRNAs and 3164 genes are differentially expressed in the Twist-induced EMT process, suggesting that Twist contributes to invasion and metastasis by inducing wide-ranging transcriptional and functional changes of IncRNAs and signaling pathways [131]. Zou et al. found that IncRNA-Hh, transcriptionally regulated by Twist, directly targets GAS1 to stimulate the activation of hedgehog signaling, thus endowing Twist-induced EMT cells to gain the cancer stem cell-like stemness properties [86]. Moreover, several reports showed that lncRNAs could in turn regulate Twist expression in multiple cancer types. In a study conducted in gastric cancer, Cai et al. demonstrated that FRLnc1 overexpression could promote cancer cell migration and metastasis and identified TGF- $\beta 1$ and Twist as the downstream effectors of FRLnc1 [132]. In CRC, Niu et al. revealed that AK027294 downregulation significantly inhibited CRC cell migration and promoted cell apoptosis by regulating Twist, caspase-3, caspase-8, Bcl-2, MMP12, MMP9 expression [133]. In gallbladder cancer, LincRNA-ROR and AFAP1-AS1 are also reported to regulate Twist expression to promote EMT process $[134,135]$. Previous work demonstrated that lncRNAs could directly interact with proteins to function as scaffolds for chromatin-remodeling complexes or other regulatory complexes [136]. One recent study showed that, an lncRNA named HOTTIP, could form a complex with Twist and WDR5, leading to the upregulation of HOXA9 and aggressive cellular phenotypes such as invasion and migration [78]. Together, these data suggest that the crosstalk between Twist and lncRNAs is rather complex and further studies are needed to investigate the more detailed underlying mechanisms.

\section{Conclusion}

EMT is a complex, multifunctional, and tightly regulated process that plays anessential role in tumor metastasis. EMT-activating signaling pathways and EMT-inducing transcription factors (EMT-TFs) are responsible for driving EMT and conferring aggressive mesenchymal properties to epithelial cells. Over the past few years, IncRNAs, which belong to a novel heterogeneous class of ncRNAs, are emerging as promising biomarkers and therapeutic targets for EMT and metastasis. Accumulating evidence has indicated that lncRNAs are widely dysregulated in a variety of malignancies to impact epithelial plasticity by targeting different signaling pathways, EMT-TFs, and EMT-related genes. The distribution and levels of lncRNAs in various locations such as distal metastases, have been exploited as potential diagnostic and prognostic biomarkers for cancer. Technologies have been advanced to achieve more sensitive and reliable detection and effective targeting of lncRNAs for cancer treatment. Despite these advances, there remain many challenges, such as limited knowledge of IncRNA functional mechanisms, targets, and binding partners, the challenges of effective delivery, stability, immunogenicity, and bioavailability of IncRNA-targeted therapeutics, all of which will be formidable tasks to undertake for the future studies. Overall, lncRNAs have shed new light on our understanding of cancer pathways and brought our understanding of tumorigenesis to a new horizon. Understanding the different and precise molecular mechanisms by which functional lncRNAs switch EMT on and off is important for opening up new avenues in IncRNA-directed diagnosis, prognosis, and therapeutic intervention against cancer. 


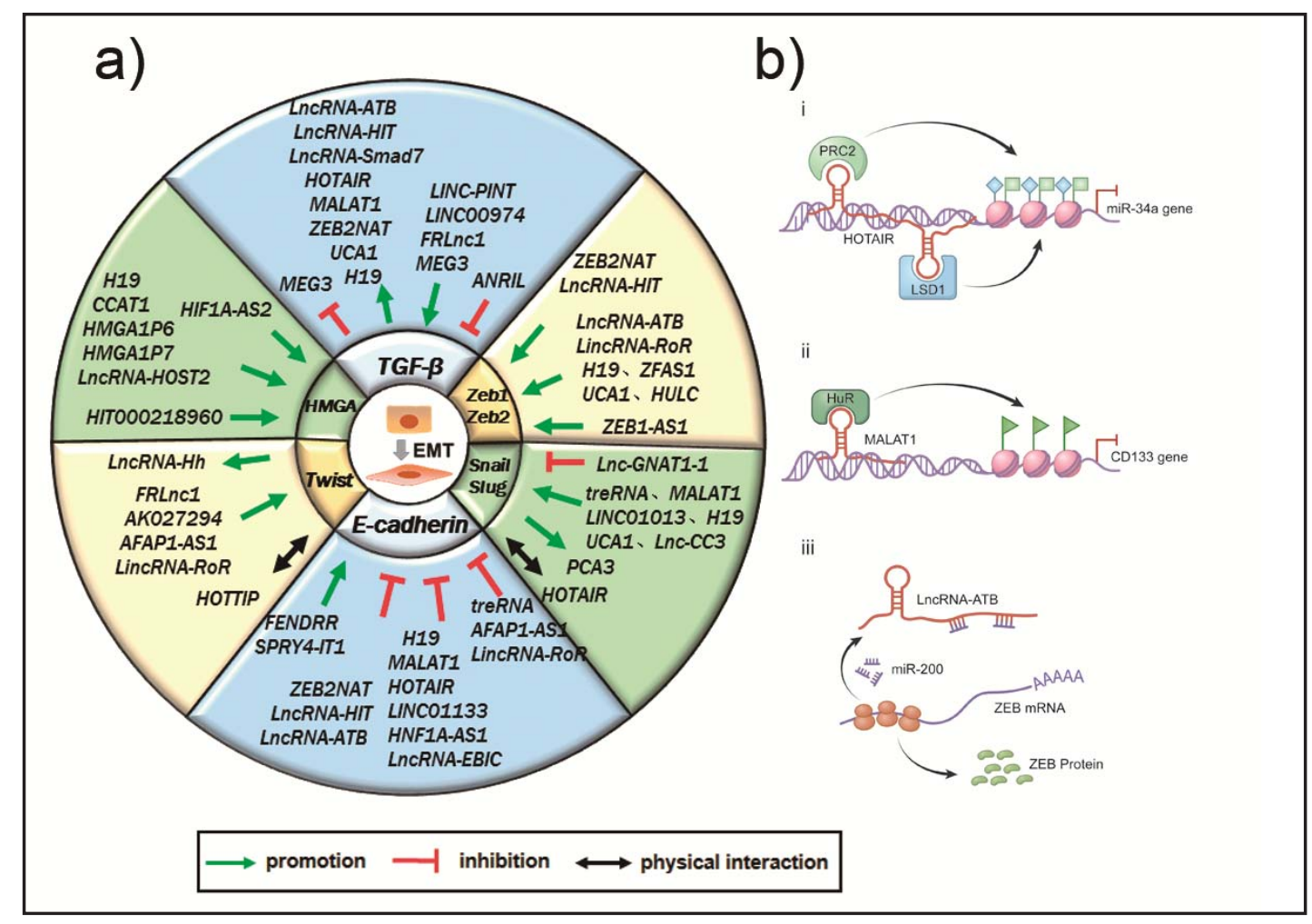

Fig. 2. Crosstalk between EMT core regulators and lncRNAs. (a). EMT can be regulated by many signaling pathways, transcription factors, and transcriptional/post-transcriptional regulators, such as TGF- $\beta$, ZEB, Snail, Twist, HMGA, etc. These EMT core regulators are reciprocally regulated by different lncRNAs, and some of EMT-inducing transcription factors (EMT-TFs) exert their effects by directly interacting with IncRNAs. (b) Selected examples of IncRNAs and their molecular partners or genomic targets are shown for mesenchymal and motility properties.

\section{Acknowledgements}

This work was supported by the National Natural Science Foundation of China [grant numbers 81602517, 81630069, 81570938, 81472631]. LW and FY are major contributors in writing the manuscript. LJ helped to draft the manuscript. LW and AY designed and revised the manuscript. All authors read and approved the final manuscript

\section{Disclosure Statement}

The author declares that they have no competing interests

\section{References}

1 Yang J, Weinberg RA: Epithelial-mesenchymal transition: At the crossroads of development and tumor metastasis. Dev Cell 2008;14:818-829.

2 De Craene B, Berx G: Regulatory networks defining EMT during cancer initiation and progression. Nat Rev Cancer 2013;13:97-110.

3 Rinn JL, Chang HY: Genome regulation by long noncoding RNAs. Annu Rev Biochem 2012;81:145-166.

4 Anko ML, Neugebauer KM: Long noncoding RNAs add another layer to pre-mRNA splicing regulation. Mol Cell 2010;39:833-834. 


\section{Cellular Physiology Cell Physiol Biochem 2017;44:1665-1680 \begin{tabular}{l|l} 
DOI: 10.1159/000485766 & O 2017 The Author(s). Published by S. Karger AG, Basel \\
www.karger.com/cpb
\end{tabular}

-5 Carrieri C, Cimatti L, Biagioli M, Beugnet A, Zucchelli S, Fedele S, Pesce E, Ferrer I, Collavin L, Santoro C, Forrest AR, Carninci P, Biffo S, Stupka E, Gustincich S: Long non-coding antisense RNA controls Uchl1 translation through an embedded SINEB2 repeat. Nature 2012;491:454-457.

6 Gong C, Maquat LE: LncRNAs transactivate STAU1-mediated mRNA decay by duplexing with 3' UTRs via Alu elements. Nature 2011;470:284-288.

7 Hung T, Wang Y, Lin MF, Koegel AK, Kotake Y, Grant GD, Horlings HM, Shah N, Umbricht C, Wang P, Wang Y, Kong B, Langerod A, Borresen-Dale AL, Kim SK, van de Vijver M, Sukumar S, Whitfield ML, Kellis M, Xiong Y, Wong DJ, Chang HY: Extensive and coordinated transcription of noncoding RNAs within cell-cycle promoters. Nat Genet 2011;43:621-629. Lee JT: Epigenetic regulation by long noncoding RNAs. Science 2012;338:1435-1439.

Wang KC, Yang YW, Liu B, Sanyal A, Corces-Zimmerman R, Chen Y, Lajoie BR, Protacio A, Flynn RA, Gupta RA, Wysocka J, Lei M, Dekker J, Helms JA, Chang HY: A long noncoding RNA maintains active chromatin to coordinate homeotic gene expression. Nature 2011;472:120-124.

10 Yoon JH, Abdelmohsen K, Srikantan S, Yang X, Martindale JL, De S, Huarte M, Zhan M, Becker KG, Gorospe M: LincRNA-p21 suppresses target mRNA translation. Mol Cell 2012;47:648-655.

11 Yang L, Lin C, Jin C, Yang JC, Tanasa B, Li W, Merkurjev D, Ohgi KA, Meng D, Zhang J, Evans CP, Rosenfeld MG: LncRNA-dependent mechanisms of androgen-receptor-regulated gene activation programs. Nature 2013;500:598-602.

12 Montes M, Nielsen MM, Maglieri G, Jacobsen A, Hojfeldt J, Agrawal-Singh S, Hansen K, Helin K, van de Werken HJ, Pedersen JS, Lund AH: The IncRNA MIR31HG regulates p16(INK4A) expression to modulate senescence. Nat Commun 2015;6:6967.

-13 Huarte M, Guttman M, Feldser D, Garber M, Koziol MJ, Kenzelmann-Broz D, Khalil AM, Zuk 0, Amit I, Rabani M, Attardi LD, Regev A, Lander ES, Jacks T, Rinn JL: A large intergenic noncoding RNA induced by p53 mediates global gene repression in the p53 response. Cell 2010;142:409-419.

14 Yang F, Zhang H, Mei Y, Wu M: Reciprocal regulation of HIF-1alpha and lincRNA-p21 modulates the Warburg effect. Mol Cell 2014;53:88-100.

15 Fan Y, Shen B, Tan M, Mu X, Qin Y, Zhang F, Liu Y: Long non-coding RNA UCA1 increases chemoresistance of bladder cancer cells by regulating Wnt signaling. FEBS J 2014;281:1750-1758.

16 Gutschner T, Hammerle M, Eissmann M, Hsu J, Kim Y, Hung G, Revenko A, Arun G, Stentrup M, Gross M, Zornig M, MacLeod AR, Spector DL, Diederichs S: The noncoding RNA MALAT1 is a critical regulator of the metastasis phenotype of lung cancer cells. Cancer Res 2013;73:1180-1189.

17 Yang F, Huo XS, Yuan SX, Zhang L, Zhou WP, Wang F, Sun SH: Repression of the long noncoding RNA-LET by histone deacetylase 3 contributes to hypoxia-mediated metastasis. Mol Cell 2013;49:1083-1096.

18 Mehlen P, Puisieux A: Metastasis: A question of life or death. Nat Rev Cancer 2006;6:449-458.

19 Polyak K, Weinberg RA: Transitions between epithelial and mesenchymal states: Acquisition of malignant and stem cell traits. Nat Rev Cancer 2009;9:265-273.

20 Tahira AC, Kubrusly MS, Faria MF, Dazzani B, Fonseca RS, Maracaja-Coutinho V, Verjovski-Almeida S, Machado MC, Reis EM: Long noncoding intronic RNAs are differentially expressed in primary and metastatic pancreatic cancer. Mol Cancer 2011;10:141.

-21 Sorensen KP, Thomassen M, Tan Q Bak M, Cold S, Burton M, Larsen MJ, Kruse TA: Long non-coding RNA expression profiles predict metastasis in lymph node-negative breast cancer independently of traditional prognostic markers. Breast Cancer Res 2015;17:55.

22 Ji P, Diederichs S, Wang W, Boing S, Metzger R, Schneider PM, Tidow N, Brandt B, Buerger H, Bulk E, Thomas M, Berdel WE, Serve H, Muller-Tidow C: MALAT-1, a novel noncoding RNA, and thymosin beta4 predict metastasis and survival in early-stage non-small cell lung cancer. Oncogene 2003;22:8031-8041.

-23 Hutchinson JN, Ensminger AW, Clemson CM, Lynch CR, Lawrence JB, Chess A: A screen for nuclear transcripts identifies two linked noncoding RNAs associated with SC35 splicing domains. BMC Genomics 2007;8:39.

24 Gutschner T, Hammerle M, Eissmann M, Hsu J, Kim Y, Hung G, Revenko A, Arun G, Stentrup M, Gross M, Zornig M, MacLeod AR, Spector DL, Diederichs S: The noncoding RNA MALAT1 is a critical regulator of the metastasis phenotype of lung cancer cells. Cancer Res 2013;73:1180-1189.

-25 Tano K, Mizuno R, Okada T, Rakwal R, Shibato J, Masuo Y, Ijiri K, Akimitsu N: MALAT-1 enhances cell motility of lung adenocarcinoma cells by influencing the expression of motility-related genes. FEBS Lett 2010;584:4575-4580. 


\section{Cellular Physiology Cell Physiol Biochem 2017;44:1665-1680 \begin{tabular}{ll|l} 
DOI: 10.1159/000485766 & $\begin{array}{l}\text { (c) } 2017 \text { The Author(s). Published by S. Karger AG, Basel } \\
\text { www.karger.com/cpb }\end{array}$
\end{tabular}}

26 Ying L, Chen Q, Wang Y, Zhou Z, Huang Y, Qiu F: Upregulated MALAT-1 contributes to bladder cancer cell migration by inducing epithelial-to-mesenchymal transition. Mol Biosyst 2012;8:2289-2294.

-27 Fan Y, Shen B, Tan M, Mu X, Qin Y, Zhang F, Liu Y: TGF-beta-induced upregulation of malat1 promotes bladder cancer metastasis by associating with suz12 Clin Cancer Res 2014;20:1531-1541.

-28 Kan JY, Wu DC, Yu FJ, Wu CY, Ho YW, Chiu YJ, Jian SF, Hung JY, Wang JY, Kuo PL: Chemokine (C-C motif) ligand 5 is involved in Tumor-Associated dendritic Cell-Mediated colon cancer progression through NonCoding RNA MALAT-1 J Cell Physiol 2015;230:1883-1894.

29 Li Q Zhang C, Chen R, Xiong H, Qiu F, Liu S, Zhang M, Wang F, Wang Y, Zhou X, Xiao G, Wang X, Jiang Q: Disrupting MALAT1/miR-200c sponge decreases invasion and migration in endometrioid endometrial carcinoma. Cancer Lett 2016;383:28-40.

30 Shi B, Wang Y, Yin F: MALAT1/miR-124/Capn4 axis regulates proliferation, invasion and EMT in nasopharyngeal carcinoma cells. Cancer Biol Ther 2017:0.

-31 Li P, Zhang X, Wang H, Wang L, Liu T, Du L, Yang Y, Wang C: MALAT1 is associated with poor response to Oxaliplatin-Based chemotherapy in colorectal cancer patients and promotes chemoresistance through EZH2. Mol Cancer Ther 2017;16:739-751.

32 Shen L, Chen L, Wang Y, Jiang X, Xia H, Zhuang Z: Long noncoding RNA MALAT1 promotes brain metastasis by inducing epithelial-mesenchymal transition in lung cancer. J Neurooncol 2015;121:101-108.

33 Latorre E, Carelli S, Raimondi I, D’Agostino V, Castiglioni I, Zucal C, Moro G, Luciani A, Ghilardi G, Monti E, Inga A, Di Giulio AM, Gorio A, Provenzani A: The ribonucleic complex HuR-MALAT1 represses CD133 expression and suppresses Epithelial-Mesenchymal transition in breast cancer. Cancer Res 2016;76:26262636.

-34 Rinn JL, Kertesz M, Wang JK, Squazzo SL, Xu X, Brugmann SA, Goodnough LH, Helms JA, Farnham PJ, Segal E, Chang HY: Functional demarcation of active and silent chromatin domains in human HOX loci by noncoding RNAs. Cell 2007;129:1311-1323.

-35 Gupta RA, Shah N, Wang KC, Kim J, Horlings HM, Wong DJ, Tsai MC, Hung T, Argani P, Rinn JL, Wang Y, Brzoska P, Kong B, Li R, West RB, van de Vijver MJ, Sukumar S, Chang HY: Long non-coding RNA HOTAIR reprograms chromatin state to promote cancer metastasis. Nature 2010;464:1071-1076.

-36 Kogo R, Shimamura T, Mimori K, Kawahara K, Imoto S, Sudo T, Tanaka F, Shibata K, Suzuki A, Komune S, Miyano S, Mori M: Long noncoding RNA HOTAIR regulates polycomb-dependent chromatin modification and is associated with poor prognosis in colorectal cancers. Cancer Res 2011;71:6320-6326.

37 Liu XH, Liu ZL, Sun M, Liu J, Wang ZX, De W: The long non-coding RNA HOTAIR indicates a poor prognosis and promotes metastasis in non-small cell lung cancer. BMC Cancer 2013;13:464.

38 Geng YJ, Xie SL, Li Q, Ma J, Wang GY: Large intervening non-coding RNA HOTAIR is associated with hepatocellular carcinoma progression. J Int Med Res 2011;39:2119-2128.

39 Padua AC, Fonseca AS, Muys BR, de Barros ELBR, Burger MC, de Souza JE, Valente V, Zago MA, Silva WJ: Brief report: The lincRNA Hotair is required for epithelial-to-mesenchymal transition and stemness maintenance of cancer cell lines. Stem Cells 2013;31:2827-2832.

40 Wu ZH, Wang XL, Tang HM, Jiang T, Chen J, Lu S, Qiu GQ, Peng ZH, Yan DW: Long non-coding RNA HOTAIR is a powerful predictor of metastasis and poor prognosis and is associated with epithelial-mesenchymal transition in colon cancer. Oncol Rep 2014;32:395-402.

-41 Liu YW, Sun M, Xia R, Zhang EB, Liu XH, Zhang ZH, Xu TP, De W, Liu BR, Wang ZX: LincHOTAIR epigenetically silences miR34a by binding to PRC2 to promote the epithelial-to-mesenchymal transition in human gastric cancer. Cell Death Dis 2015;6:e1802.

42 Wu Y, Zhang L, Zhang L, Wang Y, Li H, Ren X, Wei F, Yu W, Liu T, Wang X, Zhou X, Yu J, Hao X: Long noncoding RNA HOTAIR promotes tumor cell invasion and metastasis by recruiting EZH2 and repressing E-cadherin in oral squamous cell carcinoma. Int J Oncol 2015;46:2586-2594.

43 Hong Q Li O, Zheng W, Xiao WZ, Zhang L, Wu D, Cai GY, He JC, Chen XM: LncRNA HOTAIR regulates HIF1alpha/AXL signaling through inhibition of miR-217 in renal cell carcinoma. Cell Death Dis 2017;8:e2772.

44 Yoshimizu T, Miroglio A, Ripoche MA, Gabory A, Vernucci M, Riccio A, Colnot S, Godard C, Terris B, Jammes H, Dandolo L: The H19 locus acts in vivo as a tumor suppressor. Proc Natl Acad Sci U S A 2008;105:1241712422.

45 Matouk IJ, DeGroot N, Mezan S, Ayesh S, Abu-lail R, Hochberg A, Galun E: The H19 non-coding RNA is essential for human tumor growth. Plos One 2007;2:e845. 


\section{Cellular Physiology Cell Physiol Biochem 2017;44:1665-1680 \begin{tabular}{l|l} 
DOI: 10.1159/000485766 & Ond Biochemistry 2017 The Author(s). Published by S. Karger AG, Basel \\
wubw.karger.com/cpb
\end{tabular}

46 Gregory PA, Bert AG, Paterson EL, Barry SC, Tsykin A, Farshid G, Vadas MA, Khew-Goodall Y, Goodall GJ: The miR-200 family and miR-205 regulate epithelial to mesenchymal transition by targeting ZEB1 and SIP1 Nat Cell Biol 2008;10:593-601.

47 Zhang L, Yang F, Yuan JH, Yuan SX, Zhou WP, Huo XS, Xu D, Bi HS, Wang F, Sun SH: Epigenetic activation of the MiR-200 family contributes to H19-mediated metastasis suppression in hepatocellular carcinoma. Carcinogenesis 2013;34:577-586.

-48 Zhu M, Chen Q, Liu X, Sun Q, Zhao X, Deng R, Wang Y, Huang J, Xu M, Yan J, Yu J: LncRNA H19/miR-675 axis represses prostate cancer metastasis by targeting TGFBI. FEBS J 2014;281:3766-3775.

-49 Luo M, Li Z, Wang W, Zeng Y, Liu Z, Qiu J: Long non-coding RNA H19 increases bladder cancer metastasis by associating with EZH2 and inhibiting E-cadherin expression. Cancer Lett 2013;333:213-221.

50 Matouk IJ, Raveh E, Abu-lail R, Mezan S, Gilon M, Gershtain E, Birman T, Gallula J, Schneider T, Barkali M, Richler C, Fellig Y, Sorin V, Hubert A, Hochberg A, Czerniak A: Oncofetal H19 RNA promotes tumor metastasis. Biochim Biophys Acta 2014;1843:1414-1426.

51 Zhou W, Ye XL, Xu J, Cao MG, Fang ZY, Li LY, Guan GH, Liu Q, Qian YH, Xie D: The IncRNA H19 mediates breast cancer cell plasticity during EMT and MET plasticity by differentially sponging miR-200b/c and let-7b. Sci Signal 2017;10

52 Yuan JH, Yang F, Wang F, Ma JZ, Guo YJ, Tao QF, Liu F, Pan W, Wang TT, Zhou CC, Wang SB, Wang YZ, Yang Y, Yang N, Zhou WP, Yang GS, Sun SH: A long noncoding RNA activated by TGF-beta promotes the invasionmetastasis cascade in hepatocellular carcinoma. Cancer Cell 2014;25:666-681.

53 Shi SJ, Wang LJ, Yu B, Li YH, Jin Y, Bai XZ: LncRNA-ATB promotes trastuzumab resistance and invasionmetastasis cascade in breast cancer. Oncotarget 2015;6:11652-11663.

-54 Iguchi T, Uchi R, Nambara S, Saito T, Komatsu H, Hirata H, Ueda M, Sakimura S, Takano Y, Kurashige J, Shinden Y, Eguchi H, Sugimachi K, Maehara Y, Mimori K: A long noncoding RNA, lncRNA-ATB, is involved in the progression and prognosis of colorectal cancer. Anticancer Res 2015;35:1385-1388.

55 Saito T, Kurashige J, Nambara S, Komatsu H, Hirata H, Ueda M, Sakimura S, Uchi R, Takano Y, Shinden Y, Iguchi T, Eguchi H, Ehata S, Murakami K, Sugimachi K, Mimori K: A long non-coding RNA activated by transforming growth factor-beta is an independent prognostic marker of gastric cancer. Ann Surg Oncol 2015;22:S915-S922.

56 Loewer S, Cabili MN, Guttman M, Loh YH, Thomas K, Park IH, Garber M, Curran M, Onder T, Agarwal S, Manos PD, Datta S, Lander ES, Schlaeger TM, Daley GQ Rinn JL: Large intergenic non-coding RNA-RoR modulates reprogramming of human induced pluripotent stem cells. Nat Genet 2010;42:1113-1117.

57 Hou P, Zhao Y, Li Z, Yao R, Ma M, Gao Y, Zhao L, Zhang Y, Huang B, Lu J: LincRNA-ROR induces epithelial-tomesenchymal transition and contributes to breast cancer tumorigenesis and metastasis. Cell Death Dis 2014;5:e1287.

58 Chen Y, Peng Y, Xu Z, Ge B, Xiang X, Zhang T, Gao L, Shi H, Wang C, Huang J: LncROR promotes bladder cancer cell proliferation, migration, and Epithelial-Mesenchymal transition. Cell Physiol Biochem 2017;41:2399-2410.

59 Li L, Gu M, You B, Shi S, Shan Y, Bao L, You Y: Long non-coding RNA ROR promotes proliferation, migration and chemoresistance of nasopharyngeal carcinoma. Cancer Sci 2016;107:1215-1222.

60 Wang L, Guo ZY, Zhang R, Xin B, Chen R, Zhao J, Wang T, Wen WH, Jia LT, Yao LB, Yang AG: Pseudogene OCT4-pg4 functions as a natural micro RNA sponge to regulate OCT4 expression by competing for miR-145 in hepatocellular carcinoma. Carcinogenesis 2013;34:1773-1781.

-61 Eades G, Wolfson B, Zhang Y, Li Q Yao Y, Zhou Q: LincRNA-RoR and miR-145 regulate invasion in triplenegative breast cancer via targeting ARF6 Mol Cancer Res 2015;13:330-338.

62 Wang Y, Xu Z, Jiang J, Xu C, Kang J, Xiao L, Wu M, Xiong J, Guo X, Liu H: Endogenous miRNA sponge lincRNARoR regulates Oct4, Nanog, and Sox2 in human embryonic stem cell self-renewal. Dev Cell 2013;25:69-80.

63 Flockhart RJ, Webster DE, Qu K, Mascarenhas N, Kovalski J, Kretz M, Khavari PA: BRAFV600E remodels the melanocyte transcriptome and induces BANCR to regulate melanoma cell migration. Genome Res 2012;22:1006-1014.

64 Guo Q Zhao Y, Chen J, Hu J, Wang S, Zhang D, Sun Y: BRAF-activated long non-coding RNA contributes to colorectal cancer migration by inducing epithelial-mesenchymal transition. Oncol Lett 2014;8:869-875. 


\section{Cellular Physiology Cell Physiol Biochem 2017;44:1665-1680

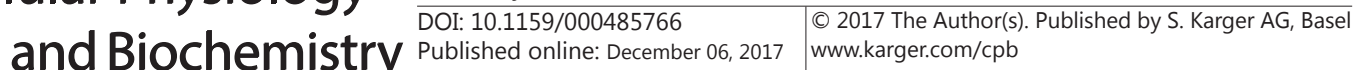

Wang et al.: Role of IncRNAs in Epithelial-Mesenchymal Transition

65 Sun M, Liu XH, Wang KM, Nie FQ, Kong R, Yang JS, Xia R, Xu TP, Jin FY, Liu ZJ, Chen JF, Zhang EB, De W, Wang ZX: Downregulation of BRAF activated non-coding RNA is associated with poor prognosis for non-small cell lung cancer and promotes metastasis by affecting epithelial-mesenchymal transition. Mol Cancer 2014;13:68.

66 Ye Z, Zhou M, Tian B, Wu B, Li J: Expression of lncRNA-CCAT1, E-cadherin and N-cadherin in colorectal cancer and its clinical significance. Int J Clin Exp Med 2015;8:3707-3715.

67 Yu Q, Zhou X, Xia Q, Shen J, Yan J, Zhu J, Li X, Shu M: Long non-coding RNA CCAT1 that can be activated by c-Myc promotes pancreatic cancer cell proliferation and migration. Am J Transl Res 2016;8:5444-5454.

68 Cui B, Li B, Liu Q, Cui Y: LncRNA CCAT1 promotes glioma tumorigenesis by sponging miR-181b. J Cell Biochem 2017

69 Zheng J, Zhao S, He X, Zheng Z, Bai W, Duan Y, Cheng S, Wang J, Liu X, Zhang G: The up-regulation of long non-coding RNA CCAT2 indicates a poor prognosis for prostate cancer and promotes metastasis by affecting epithelial-mesenchymal transition. Biochem Biophys Res Commun 2016;480:508-514.

70 Zeng J, Du T, Song Y, Gao Y, Li F, Wu R, Chen Y, Li W, Zhou H, Yang Y, Pei Z: Knockdown of long noncoding RNA CCAT2 inhibits cellular proliferation, invasion, and EMT in glioma cells. Oncol Res 2016

71 Wang YJ, Liu JZ, Lv P, Dang Y, Gao JY, Wang Y: Long non-coding RNA CCAT2 promotes gastric cancer proliferation and invasion by regulating the E-cadherin and LATS2. Am J Cancer Res 2016;6:2651-2660.

72 Yang F, Xue X, Zheng L, Bi J, Zhou Y, Zhi K, Gu Y, Fang G: Long non-coding RNA GHET1 promotes gastric carcinoma cell proliferation by increasing c-Myc mRNA stability. FEBS J 2014;281:802-813.

73 Li LJ, Zhu JL, Bao WS, Chen DK, Huang WW, Weng ZL: Long noncoding RNA GHET1 promotes the development of bladder cancer. Int J Clin Exp Pathol 2014;7:7196-7205.

74 Zhou X, Ye F, Yin C, Zhuang Y, Yue G, Zhang G: The interaction between MiR-141 and lncRNA-H19 in regulating cell proliferation and migration in gastric cancer. Cell Physiol Biochem 2015;36:1440-1452.

-75 Yang X, Song JH, Cheng Y, Wu W, Bhagat T, Yu Y, Abraham JM, Ibrahim S, Ravich W, Roland BC, Khashab M, Singh VK, Shin EJ, Yang X, Verma AK, Meltzer SJ, Mori Y: Long non-coding RNA HNF1A-AS1 regulates proliferation and migration in oesophageal adenocarcinoma cells. Gut 2014;63:881-890.

-76 Wu Y, Liu H, Shi X, Yao Y, Yang W, Song Y: The long non-coding RNA HNF1A-AS1 regulates proliferation and metastasis in lung adenocarcinoma. Oncotarget 2015;6:9160-9172.

77 Liu XH, Liu ZL, Sun M, Liu J, Wang ZX, De W: The long non-coding RNA HOTAIR indicates a poor prognosis and promotes metastasis in non-small cell lung cancer. BMC Cancer 2013;13:464.

78 Malek R, Gajula RP, Williams RD, Nghiem B, Simons BW, Nugent K, Wang H, Taparra K, Lemtiri-Chlieh G, Yoon AR, True L, An SS, DeWeese TL, Ross AE, Schaeffer EM, Pienta KJ, Hurley PJ, Morrissey C, Tran PT: TWIST1-WDR5-Hottip regulates Hoxa9 chromatin to facilitate prostate cancer metastasis. Cancer Res 2017

79 Li Z, Zhao X, Zhou Y, Liu Y, Zhou Q, Ye H, Wang Y, Zeng J, Song Y, Gao W, Zheng S, Zhuang B, Chen H, Li W, Li H, Li H, Fu Z, Chen R: The long non-coding RNA HOTTIP promotes progression and gemcitabine resistance by regulating HOXA13 in pancreatic cancer. J Transl Med 2015;13:84.

80 Zhao Y, Guo Q Chen J, Hu J, Wang S, Sun Y: Role of long non-coding RNA HULC in cell proliferation, apoptosis and tumor metastasis of gastric cancer: A clinical and in vitro investigation. Oncol Rep 2014;31:358-364.

-81 Li SP, Xu HX, Yu Y, He JD, Wang Z, Xu YJ, Wang CY, Zhang HM, Zhang RX, Zhang JJ, Yao Z, Shen ZY: LncRNA HULC enhances epithelial-mesenchymal transition to promote tumorigenesis and metastasis of hepatocellular carcinoma via the miR-200a-3p/ZEB1 signaling pathway. Oncotarget 2016;7:42431-42446.

82 Eades G, Wolfson B, Zhang Y, Li Q, Yao Y, Zhou Q: LincRNA-RoR and miR-145 regulate invasion in triplenegative breast cancer via targeting ARF6 Mol Cancer Res 2015;13:330-338.

83 Zhan HX, Wang Y, Li C, Xu JW, Zhou B, Zhu JK, Han HF, Wang L, Wang YS, Hu SY: LincRNA-ROR promotes invasion, metastasis and tumor growth in pancreatic cancer through activating ZEB1 pathway. Cancer Lett 2016;374:261-271.

84 Iguchi T, Uchi R, Nambara S, Saito T, Komatsu H, Hirata H, Ueda M, Sakimura S, Takano Y, Kurashige J, Shinden Y, Eguchi H, Sugimachi K, Maehara Y, Mimori K: A long noncoding RNA, lncRNA-ATB, is involved in the progression and prognosis of colorectal cancer. Anticancer Res 2015;35:1385-1388.

-85 Sun NX, Ye C, Zhao Q, Zhang Q Xu C, Wang SB, Jin ZJ, Sun SH, Wang F, Li W: Long noncoding RNA-EBIC promotes tumor cell invasion by binding to EZH2 and repressing E-cadherin in cervical cancer. Plos One 2014;9:e100340. 


\section{Cellular Physiology Cell Physiol Biochem 2017;44:1665-1680 \begin{tabular}{l|l} 
and Biochemistry Publ: 10.1159/000485766 & (c) 2017 The Author(s). Published by S. Karger AG, Basel \\
www.karger.com/cpb
\end{tabular}

86 Zhou M, Hou Y, Yang G, Zhang H, Tu G, Du YE, Wen S, Xu L, Tang X, Tang S, Yang L, Cui X, Liu M: LncRNAHh strengthen cancer stem cells generation in Twist-Positive breast cancer via activation of hedgehog signaling pathway. Stem Cells 2016;34:55-66.

87 Richards EJ, Zhang G, Li ZP, Permuth-Wey J, Challa S, Li Y, Kong W, Dan S, Bui MM, Coppola D, Mao WM, Sellers TA, Cheng JQ: Long non-coding RNAs (LncRNA) regulated by transforming growth factor (TGF) beta: LncRNA-hit-mediated TGFbeta-induced epithelial to mesenchymal transition in mammary epithelia. J Biol Chem 2015;290:6857-6867.

88 Wu J, Zhang J, Shen B, Yin K, Xu J, Gao W, Zhang L: Long noncoding RNA IncTCF7, induced by IL-6/STAT3 transactivation, promotes hepatocellular carcinoma aggressiveness through epithelial-mesenchymal transition. J Exp Clin Cancer Res 2015;34:116.

89 Zhou X, Liu S, Cai G, Kong L, Zhang T, Ren Y, Wu Y, Mei M, Zhang L, Wang X: Long non coding RNA MALAT1 promotes tumor growth and metastasis by inducing Epithelial-Mesenchymal transition in oral squamous cell carcinoma. Sci Rep 2015;5:15972.

90 Terashima M, Tange S, Ishimura A, Suzuki T: MEG3 long noncoding RNA contributes to the epigenetic regulation of Epithelial-Mesenchymal transition in lung cancer cell lines. J Biol Chem 2017;292:82-99.

-91 Zhang W, Shi S, Jiang J, Li X, Lu H, Ren F: LncRNA MEG3 inhibits cell epithelial-mesenchymal transition by sponging miR-421 targeting E-cadherin in breast cancer. Biomed Pharmacother 2017;91:312-319.

$\$ 92$ Wang C, Yan G, Zhang Y, Jia X, Bu P: Long non-coding RNA MEG3 suppresses migration and invasion of thyroid carcinoma by targeting of Rac1 Neoplasma 2015;62:541-549.

$\$ 93$ Ning L, Li Z, Wei D, Chen H, Yang C: LncRNA, NEAT1 is a prognosis biomarker and regulates cancer progression via epithelial-mesenchymal transition in clear cell renal cell carcinoma. Cancer Biomark 2017;19:75-83.

-94 Lu Y, Li T, Wei G, Liu L, Chen Q, Xu L, Zhang K, Zeng D, Liao R: The long non-coding RNA NEAT1 regulates epithelial to mesenchymal transition and radioresistance in through miR-204/ZEB1 axis in nasopharyngeal carcinoma. Tumour Biol 2016;37:11733-11741.

-95 Zhang M, Wu WB, Wang ZW, Wang XH: LncRNA NEAT1 is closely related with progression of breast cancer via promoting proliferation and EMT. Eur Rev Med Pharmacol Sci 2017;21:1020-1026.

\$6 Dong L, Ni J, Hu W, Yu C, Li H: Upregulation of long Non-Coding RNA PlncRNA-1 promotes metastasis and induces Epithelial-Mesenchymal transition in hepatocellular carcinoma. Cell Physiol Biochem 2016;38:836-846.

-97 Wu BQ, Jiang Y, Zhu F, Sun DL, He XZ: Long noncoding RNA PVT1 promotes EMT and cell proliferation and migration through downregulating p21 in pancreatic cancer cells. Technol Cancer Res Treat 2017:1875968207.

-98 Zheng X, Hu H, Li S: High expression of lncRNA PVT1 promotes invasion by inducing epithelial-tomesenchymal transition in esophageal cancer. Oncol Lett 2016;12:2357-2362.

-99 Yan K, Tian J, Shi W, Xia H, Zhu Y: LncRNA SNHG6 is associated with poor prognosis of gastric cancer and promotes cell proliferation and EMT through epigenetically silencing p27 and sponging miR-101-3p. Cell Physiol Biochem 2017;42:999-1012.

100 Sun M, Liu XH, Lu KH, Nie FQ, Xia R, Kong R, Yang JS, Xu TP, Liu YW, Zou YF, Lu BB, Yin R, Zhang EB, Xu L, De W, Wang ZX: EZH2-mediated epigenetic suppression of long noncoding RNA SPRY4-IT1 promotes NSCLC cell proliferation and metastasis by affecting the epithelial-mesenchymal transition. Cell Death Dis 2014;5:e1298.

101 Xie M, Nie FQ, Sun M, Xia R, Liu YW, Zhou P, De W, Liu XH: Decreased long noncoding RNA SPRY4-IT1 contributing to gastric cancer cell metastasis partly via affecting epithelial-mesenchymal transition. J Transl Med 2015;13:250.

102 Liu H, Lv Z, Guo E: Knockdown of long noncoding RNA SPRY4-IT1 suppresses glioma cell proliferation, metastasis and epithelial-mesenchymal transition. Int J Clin Exp Pathol 2015;8:9140-9146.

103 Sun J, Ding C, Yang Z, Liu T, Zhang X, Zhao C, Wang J: The long non-coding RNA TUG1 indicates a poor prognosis for colorectal cancer and promotes metastasis by affecting epithelial-mesenchymal transition. J Transl Med 2016;14:42.

104 Tan J, Qiu K, Li M, Liang Y: Double-negative feedback loop between long non-coding RNA TUG1 and miR145 promotes epithelial to mesenchymal transition and radioresistance in human bladder cancer cells. FEBS Lett 2015;589:3175-3181. 


\section{Cellular Physiology Cell Physiol Biochem 2017;44:1665-1680

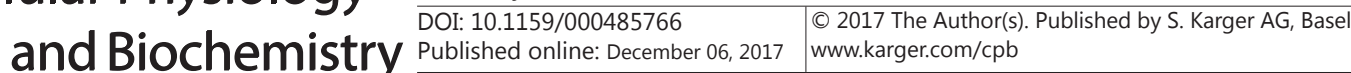

105 Ma F, Wang SH, Cai Q Jin LY, Zhou D, Ding J, Quan ZW: Long non-coding RNA TUG1 promotes cell proliferation and metastasis by negatively regulating miR-300 in gallbladder carcinoma. Biomed Pharmacother 2017;88:863-869.

106 Gumireddy K, Li A, Yan J, Setoyama T, Johannes GJ, Orom UA, Tchou J, Liu Q Zhang L, Speicher DW, Calin GA, Huang Q: Identification of a long non-coding RNA-associated RNP complex regulating metastasis at the translational step. EMBO J 2013;32:2672-2684.

107 Wang X, Ren Y, Yang X, Xiong X, Han S, Ge Y, Pan W, Zhou L, Yuan Q, Yang M: MiR-190a inhibits epithelialmesenchymal transition of hepatoma cells via targeting the long non-coding RNA treRNA. FEBS Lett 2015;589:4079-4087.

108 Xue M, Pang H, Li X, Li H, Pan J, Chen W: Long non-coding RNA urothelial cancer-associated 1 promotes bladder cancer cell migration and invasion by way of the hsa-miR-145-ZEB1/2-FSCN1 pathway. Cancer Sci 2016;107:18-27.

109 Xiao C, Wu CH, Hu HZ: LncRNA UCA1 promotes epithelial-mesenchymal transition (EMT) of breast cancer cells via enhancing Wnt/beta-catenin signaling pathway. Eur Rev Med Pharmacol Sci 2016;20:2819-2824.

110 Zuo ZK, Gong Y, Chen XH, Ye F, Yin ZM, Gong QN, Huang JS: TGFbeta1-Induced LncRNA UCA1 upregulation promotes gastric cancer invasion and migration. DNA Cell Biol 2017;36:159-167.

111 Li T, Xie J, Shen C, Cheng D, Shi Y, Wu Z, Deng X, Chen H, Shen B, Peng C, Li H, Zhan Q, Zhu Z: Upregulation of long noncoding RNA ZEB1-AS1 promotes tumor metastasis and predicts poor prognosis in hepatocellular carcinoma. Oncogene 2016;35:1575-1584.

112 Lv QL, Hu L, Chen SH, Sun B, Fu ML, Qin CZ, Qu Q, Wang GH, He CJ, Zhou HH: A long noncoding RNA ZEB1AS1 promotes tumorigenesis and predicts poor prognosis in glioma. Int J Mol Sci 2016;17

113 Li T, Xie J, Shen C, Cheng D, Shi Y, Wu Z, Deng X, Chen H, Shen B, Peng C, Li H, Zhan Q Zhu Z: Amplification of long noncoding RNA ZFAS1 promotes metastasis in hepatocellular carcinoma. Cancer Res 2015;75:31813191.

114 Zhou H, Wang F, Chen H, Tan Q, Qiu S, Chen S, Jing W, Yu M, Liang C, Ye S, Tu J: Increased expression of long-noncoding RNA ZFAS1 is associated with epithelial-mesenchymal transition of gastric cancer. Aging (Albany NY) 2016;8:2023-2038.

115 Fang C, Zan J, Yue B, Liu C, He C, Yan D: Long Noncoding RNA ZFAS1 promotes the progression of colonic cancer by modulating ZEB1 expression. J Gastroenterol Hepatol 2017;32:1204-1211.

116 Massague J: TGFbeta in cancer. Cell 2008;134:215-230.

117 Li B, Chen P, Qu J, Shi L, Zhuang W, Fu J, Li J, Zhang X, Sun Y, Zhuang W: Activation of LTBP3 gene by a long noncoding RNA (lncRNA) MALAT1 transcript in mesenchymal stem cells from multiple myeloma. J Biol Chem 2014;289:29365-29375.

118 Mondal T, Subhash S, Vaid R, Enroth S, Uday S, Reinius B, Mitra S, Mohammed A, James AR, Hoberg E, Moustakas A, Gyllensten U, Jones SJ, Gustafsson CM, Sims AH, Westerlund F, Gorab E, Kanduri C: MEG3 long noncoding RNA regulates the TGF-beta pathway genes through formation of RNA-DNA triplex structures. Nat Commun 2015;6:7743.

119 Takahashi Y, Sawada G, Kurashige J, Uchi R, Matsumura T, Ueo H, Takano Y, Eguchi H, Sudo T, Sugimachi K, Yamamoto H, Doki Y, Mori M, Mimori K: Amplification of PVT-1 is involved in poor prognosis via apoptosis inhibition in colorectal cancers. Br J Cancer 2014;110:164-171.

120 Marin-Bejar O, Marchese FP, Athie A, Sanchez Y, Gonzalez J, Segura V, Huang L, Moreno I, Navarro A, Monzo M, Garcia-Foncillas J, Rinn JL, Guo S, Huarte M: Pint lincRNA connects the p53 pathway with epigenetic silencing by the Polycomb repressive complex 2 Genome Biol 2013;14:R104.

121 Tang J, Zhuo H, Zhang X, Jiang R, Ji J, Deng L, Qian X, Zhang F, Sun B: A novel biomarker Linc00974 interacting with KRT19 promotes proliferation and metastasis in hepatocellular carcinoma. Cell Death Dis 2014;5:e1549.

122 Lamouille S, Xu J, Derynck R: Molecular mechanisms of epithelial-mesenchymal transition. Nat Rev Mol Cell Biol 2014;15:178-196.

123 Peinado H, Olmeda D, Cano A: Snail, Zeb and bHLH factors in tumour progression: An alliance against the epithelial phenotype? Nat Rev Cancer 2007;7:415-428.

124 Orom UA, Derrien T, Beringer M, Gumireddy K, Gardini A, Bussotti G, Lai F, Zytnicki M, Notredame C, Huang Q Guigo R, Shiekhattar R: Long noncoding RNAs with enhancer-like function in human cells. Cell 2010;143:46-58. 


\section{Cellular Physiology Cell Physiol Biochem 2017;44:1665-1680 \begin{tabular}{ll|l} 
DOI: 10.1159/000485766 & $\begin{array}{l}\text { O 2017 The Author(s). Published by S. Karger AG, Basel } \\
\text { www.karger.com/cpb }\end{array}$ \\
\hline
\end{tabular}}

Wang et al.: Role of IncRNAs in Epithelial-Mesenchymal Transition

-125 Tong ZT, Cai MY, Wang XG, Kong LL, Mai SJ, Liu YH, Zhang HB, Liao YJ, Zheng F, Zhu W, Liu TH, Bian XW, Guan XY, Lin MC, Zeng MS, Zeng YX, Kung HF, Xie D: EZH2 supports nasopharyngeal carcinoma cell aggressiveness by forming a co-repressor complex with HDAC1/HDAC2 and Snail to inhibit E-cadherin. Oncogene 2012;31:583-594.

126 Battistelli C, Cicchini C, Santangelo L, Tramontano A, Grassi L, Gonzalez FJ, de Nonno V, Grassi G, Amicone L, Tripodi M: The Snail repressor recruits EZH2 to specific genomic sites through the enrollment of the IncRNA HOTAIR in epithelial-to-mesenchymal transition. Oncogene 2017;36:942-955.

127 Chung IH, Lu PH, Lin YH, Tsai MM, Lin YW, Yeh CT, Lin KH: The long non-coding RNA LINC01013 enhances invasion of human anaplastic large-cell lymphoma. Sci Rep 2017;7:295.

128 Ye C, Shen Z, Wang B, Li Y, Li T, Yang Y, Jiang K, Ye Y, Wang S: A novel long non-coding RNA lnc-GNAT1-1 is low expressed in colorectal cancer and acts as a tumor suppressor through regulating RKIP-NF-kappaBSnail circuit. J Exp Clin Cancer Res 2016;35:187.

129 Jiang B, Sun R, Fang S, Qin C, Pan X, Peng L, Li Y, Li G: Lnc-CC3 increases metastasis in cervical cancer by increasing Slug expression. Oncotarget 2016;7:41650-41661.

130 Beltran M, Puig I, Pena C, Garcia JM, Alvarez AB, Pena R, Bonilla F, de Herreros AG: A natural antisense transcript regulates Zeb2/Sip1 gene expression during Snail1-induced epithelial-mesenchymal transition. Genes Dev 2008;22:756-769.

131 Hu P, Yang J, Hou Y, Zhang H, Zeng Z, Zhao L, Yu T, Tang X, Tu G, Cui X, Liu M: LncRNA expression signatures of twist-induced epithelial-to-mesenchymal transition in MCF10A cells. Cell Signal 2014;26:83-93.

132 Cai H, Chen J, He B, Li Q Li Y, Gao Y: A FOXM1 related long non-coding RNA contributes to gastric cancer cell migration. Mol Cell Biochem 2015;406:31-41.

133 Niu H, Hu Z, Liu H, Hu G, Yang B, Wu S, Li F: Long non-coding RNA AK027294 involves in the process of proliferation, migration, and apoptosis of colorectal cancer cells. Tumour Biol 2016;37:10097-10105.

134 Ma F, Wang SH, Cai Q Zhang MD, Yang Y, Ding J: Overexpression of LncRNA AFAP1-AS1 predicts poor prognosis and promotes cells proliferation and invasion in gallbladder cancer. Biomed Pharmacother 2016;84:1249-1255.

135 Wang SH, Zhang MD, Wu XC, Weng MZ, Zhou D, Quan ZW: Overexpression of LncRNA-ROR predicts a poor outcome in gallbladder cancer patients and promotes the tumor cells proliferation, migration, and invasion. Tumour Biol 2016;37:12867-12875.

136 Yang G, Lu X, Yuan L: LncRNA: A link between RNA and cancer. Biochim Biophys Acta 2014;1839:10971109. 